\title{
Pelatihan Penulisan Artikel Ilmiah pada Jurnal Nasional bagi Guru SMA Sederajat di Kabupaten Rokan Hilir Provinsi Riau
}

\author{
Isjoni, Bunari, Yuliantoro* \\ Prodi Pendidikan Sejarah, FKIP Universitas Riau \\ *Corresponding Author. Email: yuliantoro@ lecturer.unri.ac.id
}

\begin{abstract}
This service activity aims to improve understanding and practice writing skills and submit scientific articles to national journals for high school teachers and equivalent in Tanah Putih sub-district, Rokan Hilir Regency. This activity was carried out using workshop method and continued with online guidance. In the field workshop, material was presented on the definition of scientific articles and journals, why teachers are required to have the ability to research and write articles, write scientific articles and training in submitting scientific articles to online journals. The results of the training showed an increase in the ability of participants to understand the procedures for writing scientific articles and the procedure for submitting articles to national journals. The core achievement can be seen from the enthusiasm of the participants who were very good during the training and there were articles from participants who had succeeded in being submitted to reputable National Journals.
\end{abstract}

\begin{abstract}
Abstrak: Kegiatan pengabdian ini bertujuan untuk meningkatkan pemahaman dan melatih keterampilan menulis serta mensubmit artikel ilmiah pada jurnal nasional bagi para Guru SMA sederajat di kecamatan Tanah Putih Kabupaten Rokan Hilir. Kegiatan ini dilaksanakan dengan menggunakan metode workshop dan dilanjutkan dengan bimbingan secara online. Pada kegiatan workshop tatap muka, disampaikan materi mengenai definisi artikel dan jurnal ilmiah, mengapa guru wajib memiliki kemampuan untuk meneliti dan menulis artikel, tata tulis artikel ilmiah serta pelatihan mensubmit artikel ilmiah ke jurnal online. Hasil pelatihan menunjukkan peningkatan kemampuan peserta dalam memahami tata cara menulis artikel ilmiah dan prosedur mensubmit artikel ke jurnal Nasional. Ketercapaian inti terlihat dari antusiasme peserta yang sangat baik pada saat pelatihan dan terdapat artikel peserta yang telah berhasil untuk disubmit ke Jurnal Nasional.
\end{abstract}

\section{Article History:}

Received: 17-09-2021

Reviewed: 01-10-2021

Accepted: 21-10-2021

Published: 13-11-2021

Key Words:

Training, Article, Scientific Jurnal, Teacher.

\section{Sejarah Artikel:}

Diterima: 17-09-2021

Direview: 01-10-2021

Disetujui: 21-10-2021

Diterbitkan: 13-11-2021

\section{Kata Kunci:}

Pelatihan, Artikel, Jurnal Ilmiah, Guru.

How to Cite: Isjoni, I., Bunari, B., \& Yuliantoro, Y. (2021). Pelatihan Penulisan Artikel Ilmiah pada Jurnal Nasional bagi Guru SMA Sederajat di Kabupaten Rokan Hilir Provinsi Riau. Jurnal Pengabdian UNDIKMA, 2(2), 252-258. doi:https://doi.org/10.33394/jpu.v2i2.4159

https://doi.org/10.33394/jpu.v2i2.4159

This is an open-access article under the CC-BY-SA License.

\section{Pendahuluan}

Guru sebagai ilmuwan dan tenaga pendidik yang dituntut menjadi tenaga profesional membawa konsekuensi tersendiri, setiap guru harus menerapkan prinsip-prinsip profesionalitas dalam proses pembelajaran kepada semua perserta didik, di antaranya: keahlian, guru harus ahli dalam menguasai materi, kemahiran, mahir dalam mengolah pembelajaran, cakap, dalam memenuhi standar mutu menjadi seorang guru, mengetahui kode etik, jangan hanya hafal secara lisan tetapi juga mampu mengaplikasikannya dalam dunia pendidikan dan lingkungan masyarakat, dan akhirnya mendapat sertifikat profesi sebagai tenaga pendidik yang profesional, sesuai dengan yang di kehendaki dalam Undang-Undang RI No. 20 Tahun 2003 tentang Sistem Pendidikan Nasional (Sisdiknas) serta dalam UndangUndang RI No. 14 Tahun 2005 tentang guru dan Dosen. Salah satu peran guru adalah sebagai 
ilmuwan,juga berkewajiban tidak hanya menyampaikan pengetahuan yang dimiliki kepada muridnya. Akan tetapi juga berkewajiban mengembangkan pengetahuan itu dan terus menerus memupuk pengetahuan yang dimilikinya. Dengan kata lain, guru berkewajiban untuk membangun tradisi dan budaya ilmiah. Salah satunya dalam bentuk Publikasi Ilmiah. Guru pada zaman sekarang ini dituntut lebih profesional, lebih handal, dan lebih kompeten, hal itu menjadi tuntutan masyarakat modern. Maka wajar dan pantas bahwa sekarang ini menulis dalam bentuk publikasi ilmiah adalah sarana untuk meningkatkan kemampuan guru dalam pengembangan profesi mereka lebih maju.

Selain itu, guru juga berkedudukan sebagai tenaga profesional dan itu harus tertanam dalam jiwa agar mampu dan berkeinginan untuk selalu meningkatkan tanggung jawab pribadi agar dapat mengenal, memahami dan mengembangkan diri, tanggung jawab sosial, guru mampu berinteraksi secara efektif di lingkungannya dan dapat memberi kebaikan kepada orang lain, tanggung jawab intelektual, guru harus merasa wajib untuk meningkatkan penguasaan keterampilan dan up to date dalam pengetahuan untuk menunjang keprofeionalannya, tanggung jawab spiritual dan moral, maksudnya adalah dari keterampilan, perkataan, dan tingkah laku guru harus mencerminkan akhlakul karimah dan tidak menyimpang dari norma, serta guru harus memiliki tanggung jawab kesejawatan, ramah tamah dan rasa kebersamaannya menyenangkan bagi teman kerjanya. Guru perlu melaksanakan penelitian untuk megidentifikasi permasalahan pada proses pembelajaran yan terdapat di dalam kelas. Karena permasalahan yang akan dipecahkan berada di kelas maka gurulah yang paling mengetahui mengapa masalah itu muncul. Untuk mengetahui apa penyebab munculnya masalah, guru perlu menjadi peneliti. Kualitas yang tinggi diharapkan dari guru sebagai peneliti dalam sikapnya menganalisis kekurangan dalam kegiatan pembelajaran (Sukanti, 2008).

Guru sebagai garda terdepan di dalam mencerdaskan anak bangsa harus memiliki kompetensi, di antaranya kompetensi pedagogik, kompetensi sosial, kompetensi kepribadian, kompetensi bidang studi. Selain itu guru juga mesti memiliki kompetensi di dalam menulis karya ilmiah. Karena faktor inilah guru-guru yang mengalami kendala di dalam kenaikan pangkat, terutama dari golongan IV a ke atas. Menurut Yuliani (2019) secara umum rendahnya guru untuk naik pangkat ke jenjang yang lebih tinggi karena kurangnya pemahaman guru dalam mengembangkan Pengembangan keprofesian berkelanjutan (PKB) sesuai kebutuhan. Sementara itu masih banyak ditemukan karya tulis Guru yang disusun tidak ada keterkaitan dengan pengembangan profesinya. Suadiyanto (2020) menyatakan bahwa seorang Guru dan Dosen dapat dikatakan profesional apabila mereka telah melalui berbagai uji kompetensi yang salah satunya adalah mempu membuat dan menyusun karya ilmiah.

Menurut Adnan dalam Suryoputro. dkk (2012), artikel ilmiah adalah tulisan yang berisi laporan sistematis mengenai hasil kajian atau hasil penelitian yang disajikan bagi masyarakat ilmiah tertentu dan sebagai media komunikasi yang digunakan oleh peneliti dan imuwan untuk menyampaikan hasil kajian penelitian mereka. Artike ilmiah juga mmemiliki banyak jenis yang terdiri dari: 1) artikel hasil penelitian, 2) artikel non-penelitian, 3) tinjauan buku (Book review), dan 4) Obituari. Menurut Laplante dalam Farid (2017), untuk menghasilkan sebuah karya ilmiah haruslah memenuhi kaidah penulisan yang telah ditetapkan. Yang terdiri dari lima tahap yaitu" Brainstorming, drafting, revising, editing dan publisihing. 
Karya tulis ilmiah yang harus ditulis oleh guru untuk mengembangkan diri dan harus dipublikasikan kepada masyarakat sebagai bentuk kontribusi guru terhadap peningkatankualitas proses pembelajaran di sekolah danpengembangan dunia pendidikan secaraumum dan untuk memperoleh angka kreditsesuai dengan Peraturan Menteri Negara Pendayagunaan Aparatur Negara dan Reformasi Birokrasi Nomor 16 Tahun 2009 tentang Jabatan Fungsional Guru dan Angka Kreditnya adalah publikasi ilmiah. Penulisan karya ilmiah dan bentuk lainnya seperti di uraikan selanjutnya menjadi faktor kenapa guru terkendala dalam kenaikan pangkat. Ketidak tahuan atau keengganan para guru menyebabkan guru pada golongan IV a sulit untuk naik pangkat. Mereka para guru pasrah, biarlah menunggu sampai pensiun, sehingga Golongan IV b dapat mereka peroleh sebagai kenaikan pangkat Pengabdian.

Unsur di atas yang salah satu yang sulit bagi guru untuk dipenuhi oleh guru yang akan naik pangkat adalah Pengembangan Profesi, yang meliputi: Karya Tulis/ Karya Ilmiah (KTI) di bidang pendidikan, dan bidang ini dapat di kelompokkan menjadi tujuh macam kegiatan, yaitu :

1) Karya tulis ilmiah hasil penelitian, pengkajian, survey atau evaluasi dibidang pendidikan.

2) Karya tulis atau makalah yang berisi tinjauan atau ulasan ilmiah hasil gagasan sendiri di bidang pendidikan.

3) Tulisan ilmiah populer (artikel) di bidang pendidikan yang diselaraskan melalui media.

4) Prasaran yang berupa tinjauan, gagasan atau ulasan ilmiah yang disampaikan dalam pertemuan ilmiah.

5) Buku pelajaran atau modul.

6) Diktat pelajaran.

7) Karya terjemahan buku peajaran atau karya ilmiah yang bermanfaat bagi pendidikan.

Kegiatan publikasi ilmiah guru semakin diperkuat dengan hadirnya Permenpan dan RB Nomor 16 Tahun 2009 tentang Jabatan Fungsional Guru dan Angka Kreditnya. Semula kewajiban publikasi ilmiah hanya dikenakan kepada guru yang akan naik pangkat dari Golongan IV.a ke atas. Namun berdasarkan Permenpan dan RB ini, kegiatan publikasi ilmiah guru harus dilakukan guru yang akan naik ke golongan III.c. Ini merupakan kabar baik bagi dunia pendidikan nasional kita, tapi sekaligus menjadi kabar buruk dan petaka bagi beberapa oknum pendidik dalam hal ini guru yang tidak melaksanakan tugas dengan baik dan setengah hati dalam melaksanakan tugas.

Mayoritas guru di Kecamatan Tanah Putih Provinsi Riau mengalami kesulitan di dalam melakukan penulisan karya ilmiah, sehingga enggan mereka membuat karya ilmiah. Faktor utama penyebab keengganan menulis karya ilmiah adalah 'penolakan' karya tulis ilmiah yang tidak disertai dengan alasan jelas. Menurut Larasati dalam (Gunawan,2018) ada beberapa faktor yang menghambat seorang guru dalam menulis artikel ilmiah, yang diantaranyan adalah: 1) Guru terlalu sibuk dalam tugas-tugas mengajar, administratif, serta kesibukan pribadi; 2) kesulitan dalam mencari gagasan atau ide untuk menulis dan meneliti dikarenakan kurangnya bimbingan dan referensi; 3) wawasan guru tentang artikel ilmiah yang terbatas dikarenakan belum optimalnya sosialisasi dari pihak-pihak terkait. Jika guru tidak dilatih untuk meneliti, menulis dan menerbitkan artikel, akan berdampak pada kurang baiknya kualitas pembelajaran yang dilaksanakan oleh gutu, sebab kegiatan pembelajaran 
termasuk kedalam kegiatan ilmiah yang tentunya harus berlandaskan kepada kaidah-kaidah ilmiah (Supriyanto, 2015).

Berdasarkan beberapa pertimbangan diatas, maka sangat perlu diadakannya kegiatan pelatihan untuk para guru tentang bagaimana menulis karya ilmiah dalam bentuk Artikel Ilmiah, sehingga dapat memberikan motivasi bagi guru didalam menyusun artikel untuk kenaikan pangkat yang lebih tinggi. Tim pengabdian ini mencoba memperkenalkan lagi dan memberikan pelatihan kepada para guru dalam bentuk pelatihan penulisan karya ilmiah dalam bentuk jurnal ilmiah, kepada guru-guru SMA Sederajat se-Kecamatan Tanah Putih khususnya dan guru-guru Kabupaten Rokan Hilir pada umumnya.

\section{Metode Pengabdian}

Langkah-langkah digunakan di dalam pelaksanaan pengabdian penulisan artikel ilmiah adalah melalui ceramah, tanya jawab, uji coba/simulasi dan terakhir Workshop. Kegiatan di mulai dengan (1) Menanyakan pengetahuan mereka tentang penulisan karya ilmiah, (2) Memberikan beberapa judul-judul artikel ilmiah, atau dalam bentuk ulasan kepada guru-guru, (3) Menyampaikan kepada guru sistimatika penulisan karya tulis ilmiah dalam bentuk PPT atau Ulasan, (4) Menjelaskan dan memberi contoh setiap Bab/ sub bab, (5) memberikan contoh bagaimana sistimatika penulisan artikel ilmiah dalam bentuk jurnal dan cara submit jurnal. Kegiatan pengabdian kepada masyarakat ini, dilaksanakan pada bulan Juli 2021, di Kantor UPTD Kecamatan Tanah Putih Kabupaten Rokan Hilir Provinsi Riau. Dilaksanakan dengan metode tatap muka dan bimbingan online selama kurang lebih satu minggu. Materi pelatihan yang disampaikan pada kegiatan ini diantaranya adalah" 1) Definisi Artikel ilmiah dan megapa guru wajib meneliti dan menulis artike ilmiah. 2) Tata tulis artikel ilmiah. 3) panduan mensubmit artikel ilmiah ke jurnal online. 4) Bimbingan penulisan artikel ilmiah bagi guru yang membutuhkan.

\section{Hasil Pengabdian dan Pembahasan}

Materi pertama yang membahas mengenai definisi jurnal dan kewajiban guru untuk meneliti disampaikan oleh bapak Prof. Dr. Isjoni, M.Si, yang menyampaikan bahwa yang dimaksud dengan artkel ilmiah adalah sebuah tulisan yang ditulis dengan mengikuti kaidahkaidah penulisan ilmiah, ditujukan menjelaskan serta menyebarluaskan hasil penelitian yang telah terlaksana. Artikel ilmah biasanya menjadi luaran wajib sebagai bukti bahwa seorang atau sekelompok peneliti telah benar-benar melaksanakan penelitian yang bersangkutan dan sebagai bentuk tanggung jawab dan kontribusi kepada dunia intelektual, maka hasil penelitian itu harus dipublikasikan agar dapat diakses, dibaca dan dikutip oleh orang lain. Wadah untuk mempublikasikan hasil penelitian inilah yang disebut sebagai jurnal.

Mengapa seorang guru diwajibkan untuk meneliti dan menulis artikel ilmiah, salah satunya adalah sebagai tolak ukur seorang guru yang professional. guru tidak hanya dituntut untuk mampu mengajar, namun juga melakukan penelitian untuk meningkatkan proses pengajaran dan evaluasi peserta didik. Kementerian pendidikan Indonesia sudah menetapkan bahwa penelitian yang wajib dilaksanakan oleh guru adalah bentuk Penelitian Tindakan Kelas (PTK) dan hasil penelitian inilah yang dijadikan sebagai syarat untuk mendapatkan sertifikat guru yang professional. untuk itu sangat penting bagi seorang guru untuk megetahui bagaimana tata cara menulis sebiah artikel ilmiah yang nantinya bisa di publikasikan ke Jurnal.

Materi tata tulis artikel ilmiah dan panduan mensubmit artikel ke jurnal online disampaikan oleh bapak Dr. Bunari, M.Si. artikel ilmiah memiliki template yang beragam 
sesuai dengan ketentuan dari jurnal yang ehndak kita tuju, yang dimaksud dengan template adalah tata tulis (font, ukuran tulisan, gaya selingkung dan style pengutipan) dan sistematikan tulisan. Tata tulis artikel imilah biasanya memiliki kesamaan dan secara garis besar terdiri dari: abstrak, pendahuluan, metode penelitian, hasl dan pembahasan penelitian, kesimpulan dan daftar pustaka.

Abstrak terletak di awal artikel yang memuat mengenai ringkasan proses dan hasil dari penelitian yang telah kita laksanakan. Abstrak biasanay ditulis menggunakan bahasa inggris dan ada juga jurnal yang mewajibkan abstrak ditulis dengan dua bahasa, inggris dan Indonesia. Selanjutnya adalah bagian pendahuluan yang memuat latar belakang mengapa kita melaksanakan penelitian, teori-teori serta kerangka konseptual yang kita gunakan untuk menjelaskan permasalahan yang hendak kita te liti. Pada bagian metode penelitian, berisi langkah-langkah dan pendekatan yang kita gunakan untuk menjawab permasalahan penelitian kita. Pendekatan penelitian ini memiliki bentuk yang beragam disesuaikan dengan subjek penelitian yang kita teliti. Pada bagian hasil dan pembahasan memuat temuan-temuan dari proses penelitian yang telah kita laksanakan. Temuan-temuan ini dijelaskan menggunakan kaidah-kaidah penulisan ilmiah dan berisikan data-data hasil penelitian. Pada bagian kesimpulan, menjelaskan mengenai jawaban dari tujuan penelitian yang telah kita susun sebelumnya, apakah telah sesuai dengan hipotesis atau terdapat temuan-temuan baru. Kesmpulan juga berisi tentang statemen apakah penelitian yang kita lakukan telah berhasil dan layak untuk disebarluaskan dan memiliki manfaat. Terakhir adalah daftar pustaka yang berisi sumber-sumber tulisan yang kita gunakan dalam artikel ilmiah yang telah kita tulis, sumber-sumber ini dapat berupa buku, artikel ilmiah, surat kabar dan hasil wawancara. Pada materi panduan mensubmit artikel ke jurnal online, yang disampaikan oleh bapak Yuliantoro, M.Pd, diberikan contoh tahapan-tahapan dalam meregistrasi akun ke web jurnal, menyesuaikan tulisan dengan template jurnal dan proses mensubmit artikel dan proses review. Dalam hal ini diberikan contoh jurnal Heuristik yang dikelola oleh prodi pendidikan sejarah Universitas Riau.
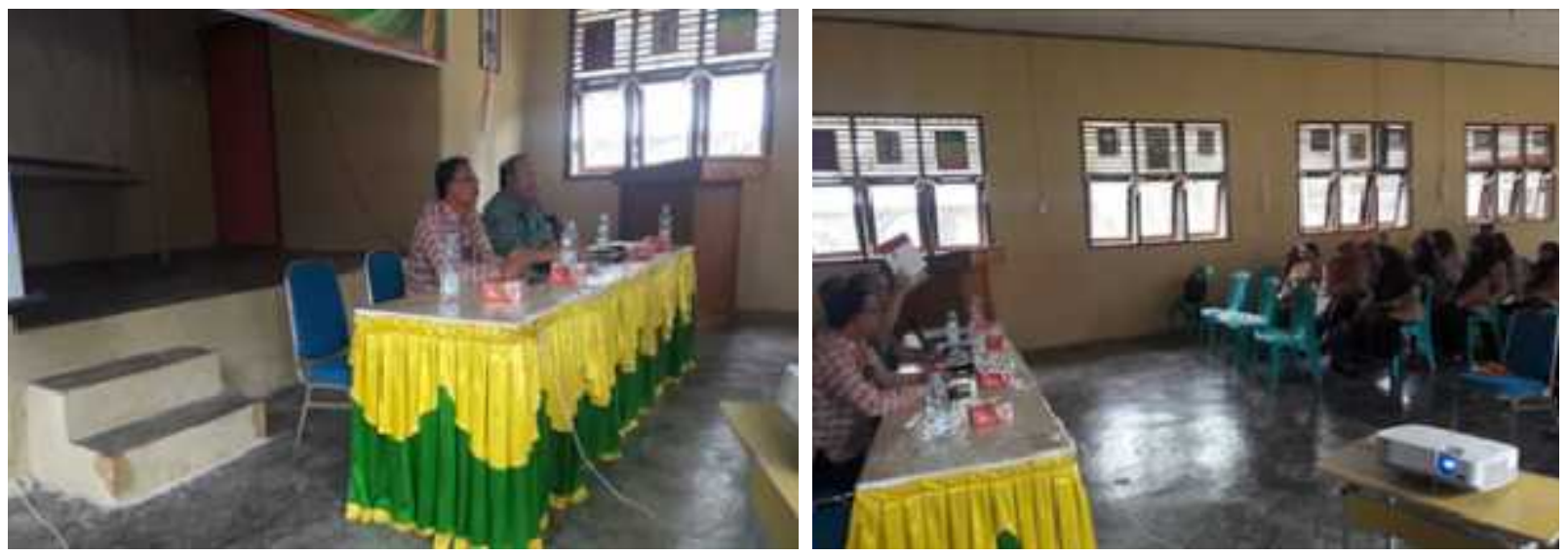

Gambar 1. Dokumentasi Kegiatan Pengabdian

Untuk kegiatan tambahan yang dilaksanakan secara online, terdiri dari bimbingan pembuatan dan penulisan artikel ilmiah. Peserta dari kegiatan ini adalah para guru yang ingin mengajukan serfifikasi guru, sehingga bagi mereka diwajibkan untuk mempublikasikan hasil penelitian tindakan kelas ke jurnal online.

Hasil pelatihan menunjukkan adanya peningkatan pemahaman dan keterampilan dari para peserta untuk mampu membuat artikel ilmiah dan mensubmitnya ke jurnal ilmiah. Ini 
bisa terlihat dari tugas yang dikerjakan oleh peserta pelatihan memperlihatkan hasil yang baik. Dari 32 peserta yang mengikuti pelatihan secara tatap muka, sepuluh peserta lanjut mengikuti bimbingan penulisan artikel secara daring. Bimbingan artikel lanjutan ini bertujuan untuk membantu peserta pelatihan untuk sampai pada tahap submit artikel ilmiah ke jurnal nasional.

\section{Kesimpulan}

Kesimpulan yang diperoleh dari hasil kegiatan pengabdian ini adalah sebagai berikut: Partisipasi peserta dalam mengikuti kegiatan pelatihan penulisan karya ilmiah sangat terlihat baik. Hal ini terbukti dengan jumlah kehadiran peserta dari guru-guru yang penuh serta mengikuti kegiatan dengan antusiasme dari awal sampai akhir kegiatan pelatihan. Kesimpulan kegiatan pelatihan ini menunjukkan sebuah grafik peningkatan pemahaman dan keterampilan guru-guru peserta dalam melaksanakan pelatihan penulisan karya ilmiah dalam bentuk artikel untuk diterbitkan dalam bentuk jurnal. Selain itu, pelatihan mempunyai efektivitas dan efisiensi yang tinggi karena guru memang membutuhkan materi pelatihan penulisan karya ilmiah untuk menunjang karir dan tuntutan profesinya.

\section{Saran}

Berdasarkan evaluasi yang telah dilakukan dapat diajukan beberapa saran sebagai berikut: (1) Kepada peserta pelatihan hendaknya setiap tahun rutin untuk menerapkan model dan metode baru dalam pembelajaran yang hasilnya nanti dapat dijadikan sebagai bahan untuk menulis artikel ilmiah sehingga keterampilan itu tetap terasah dan memberikan manfaat baik bagi guru maupun bagi peserta didik. (2) Kepada pihak FKIP Universitas Riau, diharapkan untukterus mendukung keterlaksanaan kegiatan lanjutan yang berupa pelatihan sejenis yang selalu diselenggarakan secara periodik sehingga dapat meningkatkan kemampuan guru-guru Se-Riau dalam menulis artikel ilmiah yang juga merupakan bagian dari upaya mendukung gerakan literasi nasional dan syarat kenaikan pangkat guru.

\section{Daftar Pustaka}

Anik Yuliani. (2019). Kunci Sukses Kenaikan Pangkat Guru dan Pengawas Sekolah/Madrasah. Ponorogo: Uwais Inspirasi Indonesia.

Sukanti, (2008). Meningkatkan kompetensi guru melalui pelaksanaan penelitian tindakan kelas. Jurnal Pendididkan Akutansi Indonesia Vol. VI No. 1 tahun 2008. (1-11)

Gunawan Suryoputro, Sugeng Riyadi dan Ali Sya'ban (2012). Menulis artikel untuk jurnal ilmiah, Jakarta. Uhamka Press.

Muhammad Farid (2017). Menulis artikel ilmiah,proses menemukan ide hingga publikasi. Disampaikan di seminar penulisan Artikel Ilmiah, perhimpunan pelajar Indonesia (PPI) NPUST Campus, Pingtung, 28 Oktober 2017

Imam Gunawan, Teguh Triwiyanto, Desi Eri Kusumaningrum (2018). Pendampingan Penulisan Artikel Ilmiah bagi Para Guru Sekolah Menengah Pertama. Abdimas Pedagogi: Jurnal Ilmiah Pengabdian kepada Masyarakat Vol 1, No 2 http://dx.doi.org/10.17977/um050v1i2p128-135

Supriyanto, A. (2015). Harapan, Kenyataan dan Strategi Peningkatan Kemampuan Guru dalam Penulisan Karya Tulis Ilmiah, (Online), (http://ap.fip.um.ac.id/wpcontent/uploads/2015/04/13_A-Supriyanto-AP.pdf), diakses 12 Februari 2021.

Sukanti.(2008) Meningkatkan Kompetensi Guru Melalui Pelaksanaan Penelitian Tindakan Kelas, Jurnal Pendidikan Akuntansi Indonesia Vol. Vi No. 1. 
Suadiyatno, T., Sumarsono, D., Muliani, M., Arrafii, M., \& Bagis, A. (2020). Pelatihan Strategi Penulisan Artikel Ilmiah pada Jurnal Bereputasi Nasional dan Internasional bagi Guru di SMKN 1 Sekotong Kabupaten Lombok Barat. Jurnal Pengabdian UNDIKMA, 1(2), 139-143. doi:https://doi.org/10.33394/jpu.v1i2.2936

Undang-Undang RI No. 20 Tahun 2003 tentang Sistem Pendidikan Nasional (Sisdiknas)

Undang-Undang RI No. 14 Tahun 2005 tentang guru dan Dosen.

Peraturan Menteri Pendayagunaan Aparatur Negara dan Reformasi Birokrasi (Permen PANRB) No 16 Tahun 2009 Tanggal 10 November 2009. 